\title{
Efektifitas Pijat Oksitosin terhadap Produksi Air Susu Ibu (ASI) pada Ibu Post Partum Sectio Caesaria (SC) di Ruang Kalimaya Bawah RSUD dr. Slamet Garut
}

\author{
Gin Gin Sugih Permana ${ }^{1}$, K. Dewi Budiarti ${ }^{2}$, Tantri Puspita ${ }^{3}$
}

\begin{abstract}
Abstrak
Angka Kematian Bayi (AKB) disebabkan oleh rendahnya pemberian ASI ekslusif. Salah satunya dikarenakan kurangnya produksi ASI pada hari pertama setelah melahirkanyang dapat disebabkan oleh kurangnya rangsangan hormon oksitosin dan prolaktin yang sangat berperan dalam kelancaran produksi ASI. Untuk pengeluaran ASI dibutuhkan upaya nonfarmakologis salah satunya pijat oksitosin. Pijat oksitosin sangat membantu dalam proses pengeluaran ASI. Adapun tujuan dari penelitian ini untuk mengetahui efektifitas pijat oksitosin terhadap produksi ASI pada ibu post partum di Ruang Kalimaya Bawah RSUD dr. Slamet Garut Tahun 2018. Metode penelitian ini menggunakan metode quasy eksperiment dengan rancangan pretest-posttest with Control group, penelitian dilaksanakan selama 30 hari teknik pengambilan sampel dengan "accidental sampling"dengan 20 responden kelompok kontrol dan 20 responden kelompok intervensi. Hasilnya Pada kelompok kontrol hanya (30\%) responden yang ASInya keluar pada hari ke 3, sedangkan pada kelompok intervensi $(100 \%)$ responden ASI keluar pada hari ke 3. Uji Wilcoxon p-value 0.000 yang berarti $p<\alpha 0.005$. Kesimpulan dari penelitian ini adalah ada pengaruh pijat oksitosin terhadap produksi ASI pada ibu post partum. Setiap petugas kesehatan atau bidan hendaknya mengaplikasikan pijat oksitosin pada ibu post partum agar ibu tetap memberikan ASI ekslusif pada bayi.
\end{abstract}

Kata kunci : Ibu post partum, pijat oksitosin, produksi ASI

\section{Abstract}

Infant Mortality Rate (IMR) is caused by a lack of exclusive breast feeding. One of them due to the lack of production of breast milk on the first day after delivery that can be caused by a lack of stimulation oxytocin and prolactin hormon. There are two hormones that essential to producebreast milk.For expenditure nonfarmakologis effort is needed in the form of oxytocin breast massage. Oxytocin massage is very helpful in the process of spending on breast milk. Objectivesi is To find out the effectiveness of massage oxytocin breast milk production in the mother against the post partum in the Kalimaya Bawah Hospital Dr. Slamet Garut the year 2018. The Methods used is the study was hised quasy experimentsmethod with pretest-posttest with Control group, the study was carried out during the 30 days of sampling technique with "accidental sampling". This study was included 20 respondents as a control group and other 20 respondents as intervention group. Results in the control group was found that only $30 \%$ respondents who the breast milk out on day 3, while the intervention group $100 \%$ of the respondents breast milk out on day 3. Wilcoxon test showed that p-value 0.000 meaning $\alpha<p$ 0,005. The conclusion this study is there was an influence of oxytocin massage against the production of breast milk in the mother post partum. Every health worker or midwife should apply the massage of oxytocin on the mother post partum, so that mothers could provide exclusive breast milk in infants.

Keywords : Oxytocin massage, the production of breast milk, the mother of post partum

\section{PENDAHULUAN}

$\begin{array}{rcccc}\text { Angka } & \text { Kematian } & \text { Bayi } & \text { (AKB) } & \text { kematian bayi dan angka kematian anak 1- } \\ \text { merupakan } & \text { gabungan } & \text { antara } & \text { angka } & 4 \text { tahun. Angka kematian bayi penting }\end{array}$


dalam mengukur taraf kesehatan masyarakat. Angka kematian bayi ini merupakan indikator yang sensitif untuk mengukur dalam status bayi dan anak. Di negara berkembang kematian bayi biasanya disebabkan oleh infeksi dan asupan gizi kurang. Angka kelahiran tinggi, jarak antar kelahiran pendek, keadaan sosial ekonomi, dan tingkat pendidikan yang rendah mempengaruhi angka kematian bayi (Budiarto, 2008).

Data AKB menurut World Health Organization (WHO) angka kematian bayi di Indonesia tahun 2014 mencapai 27 per 1000 kelahiran hidup. Pada saat ini Angka Kematian Bayi (AKB) di Indonesia masih tinggi dari negara ASEAN lainnya, kalau dibandingkan dengan target dari Sustainable Development Goals (SDG's) tahun 2015 yaitu mencapai 23 per 1000 kelahiranhidup. Berdasarkan data dari Dinas Kesehatan Kabupaten Garut (DinKes, Kabupaten Garut 2016), jumlah kasus Angka Kematian Bayi di Kabupaten Garut pada tahun 2016 sebanyak 333 kasus dan Kematian bayi tahun 2016 yang terjadi di Rumah Sakit yaitu sebanyak 225 kasus. Apabila dibandingkan dengan tahun 2015 jumlah kasus kematian bayi mengalami peningkatan sebanyak 55 kasus.

Dengan meningkatnya AKB, akan mengakibatkan terjadinya morbiditas tinggi. Morbiditas atau kesakitan pada bayi merupakan hal yang harus dihindari. Karena hal ini dapat berpengaruh pada status gizi bayi yang akhirnya akan berdampak pada pertumbuhan bayi, maka dari itu penyebab morbiditas yang paling banyak ditemui pada bayi muda adalah infeksi. Penyakit infeksi sendiri dapat menyebabkan bayi tidak napsu makan sehingga mempengaruhi pertumbuhan. Salah satu penyebab dari morbiditas tinggi tersebut bayi akan mengalami diare, common cold (batuk dan flu kurang dari 6 bulan) dan demam. Maka dari itu, perlu berikan jenis asupan nutrisi pada bayi paling tepat yaitu dengan pemberianASI Ekslusif (Manuaba, 2008).

ASI ekslusif adalah pemberian ASI sedini mungkin setelah persalinan tanpa jadwal dan tidak juga diberikan makanan tambahan yang lain, walaupun hanya air putih sampai bayi berumur 6 bulan (Hubertin, 2012). Pada dasarnya, ASI merupakan jenis makanan yang dapat mencukupi seluruh unsur kebutuhan bayi baik fisik, fsikologi, sosial maupun spiritual. ASI juga mengandung nutrisi, hormon, unsur kekebalan tubuh, anti alergi serta anti imflamasi. Salah satunya yaitu kolostrum yang banyak mengandung sel darah putih, protein dan antibodi yang dapat memberikan perlindungan bayi sampai usia 6 bulan.

ASI diproduksi oleh kelenjar payudara pada bulan terakhir masa kehamilan dengankondisi normal pada hari pertama dan kedua sejak bayi lahir, air susu yang dihasilkan sekitar 50-100 ml 
sehari. Jumlah ASI akan meningkat hingga $500 \mathrm{ml}$ pada minggu kedua. Produksi ASI semakin efektif dan akan terus meningkat pada 10-14 hari setelah melahirkan (Prasetyono, 2009). Pada saat itu, produksi ASI belum keluar banyak dan ibu menyangka bahwa ASI sedikit. Kemudian ibu menjadi tidak bersemangat untuk menyusui bayinya serta menyambung dengan susu formula.

Akibatnya, ASI yang kurang diproduksi akan semakin sedikit produksinya, dibanding ASI yang sering diproduksi. ASI yang tidak keluar ataupun kurang akan menyebabkan terhambat produksi ASI serta asupan nutrisi bayi tidak terpenuhi (Budiasih, 2008).

Faktor yang berpengaruh dalam produksi ASI yaitu faktor sosial budaya, faktor psikologis, faktor fisik ibu (ibu sakit mastitis,panas dll), faktor kurangnya petugas kesehatan sehingga masyarakat kurang mendapatkan informasi dan dorongan tentang pemanfaatan ASI serta seiring berjalannya waktu, zaman semakin modern sehingga terjadinya peningkatan mengenai promosi susu kaleng ataupun susu formula sebagai pengganti ASI (Soetjiningsih, 2012).

Susu formula merupakan susu yang tidak memiliki antibodi. Selain itu, apabila susu fomula diberikan pada bayi denganusia kurang dari enam (6) bulan maka akan meningkatkan risiko munculnya penyakit yang ditularkan melalui air. Maka dari itu, malnutrisi dapat menjadi ancaman bagi bayi yang telah diberikan susu formula yang terlalu encer (Nurheti, 2010). Bayi dibawah umur enam (6) bulan yang diberikan makanan pendamping selain pemberian ASI ekslusif akan berisiko 17 kali lebih besar mengalami diare dan 3-4 kali lebih besar kemungkinan terkena Infeksi Saluran Pernafasan Atas (ISPA) dibanding dengan bayi yang hanya diberikan ASI ekslusif.

Pemberian makanan padat atau makanan tambahan sejak dini, akan terganggunya pemberian ASI ekslusif, dan mengakibatkan meningkat angka kesakitan bayi. Dengan diberikan ASI ekslusif kebutuhan nutrisi bayi akan terpenuhi. Sebab, di dalam ASI mengandung protein, karbohidrat, lemak, dan mineral yang seimbang. ASI ekslusif tersebut dapat meningkatkan perkembangan otak anak dan meningkatkan daya tahan tubuh pada anak (Roesli, 2009).

Salah satu upaya untuk meningkatkan produksi ASI yaitu dengan adanya rangsangan isapan bayi. Isapan bayi ini akan menimbulkan rangsangan terhadap neuroendokrin sebagai peningkatan sekresi berupa beta endorphin, thyroid stimulating dan hormon cholecystokinin sedangkan yang akan menyebabkan sekresi pada produksi ASI ini diantaranya yaitu puisasi $L H$, corticotropin relaxing factor (CRF) menekansekresi dari LHR Factor. Isapan 
bayi juga akan menimbulkan rangsangan berantai dalam pengeluaran oksitosin (refleks semprotan ASI) dan mengeluarkan prolactin sehingga produksi ASI dapat dipertahankan (Manuaba dkk, 2009).

Meningkatkan produksi ASI, perlu dilakukan isapan ekternal seperti IMD (Inisiasi Menyusui Dini) berlangsung minimal 1 jam dengan posisi bayi melekat di dada ibu. Semakin banyak bayi menyusu maka produksi ASI juga akan semakin bertambah. IMD sangat penting tidak hanya untuk bayi tetapi untuk ibu juga sangatlah bermanfaat. Manfaat IMD yaitu menekan plasenta, mengecilkan rahim ibu, berhenti pendarahan ibu, dan meningkat rasa kasih sayang (Yuliarti, 2010).

Tetapi tidak semua ibu postpartum bisa langsung mengeluarkan ASI setelah persalinan, pengeluaran ASI merupakan suatu interaksi yang sangat komplek antara rangsangan mekanik, saraf dan bermacammacam hormon berpengaruh pada pengeluaran oksitosin. Pengeluaran hormon oksitosin selain dipengaruhi oleh isapan bayi, juga dipengaruhi oleh reseptor yang terletak pada sistem duktus, bila duktus melebar atau menjadi lunak maka secara reflektoris dikeluarkan oksitosin oleh hipofise yang berperan memeras air susu dari alveoli (Rahayu, 2016).

Perlu adanya upaya untuk pengeluaran ASI pada ibu postpartum. Dalam upaya pengeluaran ASI ada 2 hal yang mempengaruhi diantaranya, produksi dan pengeluaran. Produksi ASI biasanya dipengaruhi oleh hormon prolaktin sedangkan pengeluaran dipengaruhi oleh hormon oksitosin. Hormon oksitosin akan keluar dengan melalui rangsangan ke puting susu melalui isapan mulut bayi atau melalui pijatan pada tulang belakang ibu, dengan dilakukan pijatan pada tulang belakang ibu akan merasa tenang, rileks, meningkatkan ambang rasa nyeri sehingga dengan begitu hormon oksitosin keluar dan ASI pun cepat keluar (Yuliarti, 2010).

Jika ASI terus terhambat dan asupan nutrisi pada bayi kurang terpenuhi,maka langkah untuk meningkatkan produksi ASI agar tetap memproduksi lebih banyak yaitu, perlu dilakukannya terapi pijat oksitosin. Pijat oksitosin atau disebut juga pijat ASI dan sering dilakukan untuk meningkatkan ketidaklancaran produksi ASI, pijat dilakukan untuk merangsang reflex oksitosin atau reflex let down. Selain dapat merangsang reflex let down manfaat pijat oksitosin juga memberi kenyamanan ibu, mengurangi bengkak (engorgement), mengurangi sumbatan ASI, merangsang pelepasan hormon oksitosin, serta pempertahankan produksi ASI ketika ibu dan bayi sakit.

Pijat ASI adalah pemijatan pada sepanjang tulang belakang (vertebrae) sampai tulang costae kelima-keenam dan merupakan usaha merangsang hormon prolaktin dan oksitosin setelah melahirkan. 
Pijat oksitosin adalah tindakan yang dilakukan oleh suami pada ibu menyusui yang berupa black massage pada punggung ibu dan untuk meningkatkan pengeluaran hormone oksitosin, pijat oksitosin yang dilakukan suami memberikan kenyamanan pada ibu, sehingga akan memberikan kenyamanan pada bayi yang menyusui. Tujuan dari pijat oksitosin ini agar dapat memberikan ASI maksimal, hormon yang berperan yaitu hormon oksitosin akan terjadi stimulasi, sel-sel alveoli di kelenjar payudara berkontraksi dan menyebabkan air susu keluar mengalir dalam saluran kecil payudara, sehingga keluarlah tetesan air susu (Rahayu, 2016).

Berdasarkan penelitian Asiyah dan Wigati (2015), tentang "Minyak Aromaterapi Lavender sebagai Media Peningkatan Produksi ASI" menunjukan bahwa terdapat hubungan tidak bermakna antara pijat menggunakan minyak aromaterapi lavender dengan peningkatan produksi ASI dilihat dari pengeluaran BAB/BAK bayi. Berdasarkan penelitian Rahayu dan Andriyani (2014), berjudul "Metode Memperbanyak Produksi ASI pada Ibu Post Sectio Caesarea dengan Tehnik Marmet dan Breast Care di RSUD Karanganyar", menunjukan bahwa tidak ada perbedaan tekhnik marmet dan breast care terhadap produksi ASI; penelitian Gunanegara dkk, (2010), yang berjudul "Efektivitas Ekstrak Daun Katuk dalam Produksi Air Susu Ibu untuk Keberhasilan
Menyusui" menunjukan bahwa Pemberian ekstrak daun katuk tidak lebih baik dibandingkan plasebo dalam keberhasilan menyusui ASI. Inisiasi menyusui dini kurang dari 1 jam pasca salin berperan dalam keberhasilan menyusui ASI.

Hasil studi pendahuluan yang didapat dari rekam medik pasien RSUD dr. Slamet Garut bahwa ibu post partum spontan dari bulan Januari sampai bulan Desember 2016 sebanyak lima ribu tiga puluh delapan (5038) orang serta pada tahun 2017 dari bulan Januari sampai bulan November sebanyak dua ribu seratus enam puluh tiga (2163) orang post partum spontan. Saat dilakukan wawancara pada bidan dan perawat di Ruang Kalimaya Bawah RSUD dr. Slamet Garut mengatakan tidak pernah dilakukan pijat oksitosin pada ibu post partum, baik untuk keluarnya ASI, mengatasi pendarahan, maupun merangsang keluarnya ASI. Jadi metode untuk meningkatkan produktivitas ASI atau memperlancar keluarnya ASI yaitu dengan melalui terapi seperti terapi pijat oksitosin dan terapi ini di Ruangan Kalimaya Bawah RSUD dr. Slamet Garut belum pernah diterapkan.

Pada saat studi pendahuluan mengenai produksi ASI pada ibu post partum dengan jumlah 10 orang ibu post partum di Ruangan Kalimaya Bawah RSUD dr. Slamet Garut. Pada hari pertama seluruh pasien $100 \%$ belum mengeluarkan ASI. Pada hari ke dua terdapat hanya 
sebagian kecil (20\%) ibu post partum yang keluar ASInya, dengan riwayat persalinan $\mathrm{ibu}$ yang pertama multigravida dan ibu yang ke dua secundigravida itupun ASInya belum cukup keluar banyak. Sehingga, ASI tersebut harus dipompa keluar serta ditampung dalam botol untuk diberikan pada bayinya. Sedangkan pada hari ke tiga terdapat $(30 \%)$ ibu post partum yang keluar ASInya dengan riwayat persalinan multigravida dan 2 orang primigrafida dengan 1 orang ibu pernah mengalami abortus 2 kali. Masih pada hari yang sama terdapat (50\%) ibu post partum belum ke keluar ASInya dengan riwayat persalinan 3 orang ibu dengan riwayat persalinan primigrafida dan 2 orang ibu dengan riwayat persalinan secundigravida.

\section{METODE PENELITIAN}

Desain penelitian ini menggunakan metode kuantitatif dengan penelitian Quasi eksperimen. Pada penelitian ini teknik sampel yang digunakan adalah "accidental sampling”. Analisa data yang digunakan dalam penelitian ini adalah analisa univariat dan analisa bivariat

\section{HASIL DAN PEMBAHASAN}

\section{Hasil Penelitian}

Tabel 1. Distribusi Frekuensi Kategori Pengeluaran ASI pada Kelompok Kontrol di Ruang Kalimaya Bawah RSUD dr. Slamet Garut

\begin{tabular}{lcc}
\hline Pengeluaran ASI & $\begin{array}{c}\text { Frekuensi } \\
(\mathbf{F}) \mathbf{n}=\mathbf{2 0}\end{array}$ & $\begin{array}{c}\text { Persentasi } \\
(\mathbf{\%})\end{array}$ \\
\hline ASI keluar & 6 & 30 \\
ASI tidak keluar & 14 & 70 \\
\hline
\end{tabular}

Tabel 1 menunjukan bahwa rata-rata ibu post partum SC kelompok kontrol hampir setengahnya (30\%) pada hari ketiga tidak mengeluarkan ASI.

Tabel 2. Distribusi Frekuensi Kategori Pengeluaran Produksi ASI pada Kelompok Kontrol di Ruang Kalimaya Bawah RSUD dr. Slamet Garut

\begin{tabular}{ccc}
\hline Produksi ASI & $\begin{array}{c}\mathrm{F} \\
(\mathrm{n}=20)\end{array}$ & $\begin{array}{c}\text { Persentasi } \\
(\%)\end{array}$ \\
\hline Tindakan 1 & 0 & 0 \\
Tindakan 2 & 0 & 0 \\
Tindakan 3 & 0 & 0 \\
Tindakan 4 & 0 & 0 \\
Tindakan 5 & 2 & 10 \\
Tindakan 6 & 4 & 20 \\
\hline
\end{tabular}

Tabel 2 menunjukan pengeluaran produksi ASI pada ibu post partum SC kelompok kontrol sebagian besar produksi ASI keluar pada hari ke tiga atau pada tindakan ke enam, 4 responden (20\%).

Tabel 3. Distribusi Frekuensi Kategori Pengeluaran ASI pada kelompok Intervensi di Ruang Kalimaya Bawah RSUD dr. Slamet Garut

\begin{tabular}{lcc}
\hline Pengeluaran ASI & $\begin{array}{c}\text { Frekuensi } \\
(\mathrm{F}) \mathrm{n}=20\end{array}$ & $\begin{array}{c}\text { Persentasi } \\
(\%)\end{array}$ \\
\hline ASI keluar & 20 & 20 \\
ASI tidak keluar & 0 & 0 \\
\hline
\end{tabular}

Tabel 3 menunjukan bahwa rata-rata ibu post partum SC kelompok intervensi seluruhnya (100\%) pada hari ketiga tindakan 5 mengeluarkan ASI.

Tabel 4. Distribusi Frekuensi Kategori Pengeluaran Produksi ASI pada Kelompok Intervensi di Ruang Kalimaya Bawah RSUD dr. Slamet Garut

\begin{tabular}{ccc}
\hline Produksi ASI & $\begin{array}{c}\mathrm{F} \\
(\mathrm{n}=20)\end{array}$ & $\begin{array}{c}\text { Persentasi } \\
(\%)\end{array}$ \\
\hline Tindakan 1 & 0 & 0 \\
Tindakan 2 & 3 & 15 \\
Tindakan 3 & 8 & 40 \\
Tindakan 4 & 6 & 60 \\
Tindakan 5 & 3 & 15 \\
Tindakan 6 & 0 & 0 \\
\hline Total & 20 & 100 \\
\hline
\end{tabular}


Tabel 4 menunjukan bahwa pengeluaran produksi ASI pada ibu post partum SC sebagian besar produksi ASI keluar pada hari ke 2 atau pada tindakan ke tiga 8 responden (40\%).

Data hasil penelitian ASI keluar minimal pada hari ke 1 pada tindakan ke 2 sedangkan ASI keluar maksimal pada hari ke 3 pada tindakan ke 5, dengan kriteria inklusi dan ekslusi. Adapun kriteria inklusi pada penelitian ini :

1. Responden mampu baca dan tulis.

2. Ibu post partum $S C$ pada hari pertama yang belum mengeluarkan ASI.

3. Kondisi bayi normal / tidak meninggal.

4. Ibu post partum yang masih dirawat inap di RSU dr Slamet Garut

5. Ibu tidak sedang mengkonsumsi obatobatan pelancar keluarnya ASI.

6. Ibu post partum yang mau menyusui.

Kriteria ekslusi dalam penelitian ini adalah

1. Ibu post partum yang bayinya meninggal dunia.

2. Ibu post partum dengan masalah kesehatan lainnya, meliputi HB rendah (5 g/dl), tekanan darah tinggi, sakit hebat operasi SC.

Tabel 5. Perbandingan Produksi ASI pada Ibu Post Partum SC pada Kelompok Kontrol dan Intervensi di Ruang Kalimaya Bawah RSUD dr. Slamet Garut Tahun 2018

\begin{tabular}{cccc}
\hline Kelompok & N & Mean & P Value \\
\hline Kontrol & 20 & 3.50 & \\
Intervensi & 20 & 10.50 & $P=0.000$ \\
\hline
\end{tabular}

Berdasarkan hasil pengujian hipotesis pada tabel 5 diatas menunjukan bahwa pengaruh pijat oksitosin terhadap produksi ASI di Ruang Kalimaya Bawah RSUD dr. Slamet Garut Tahun 2018 ada perbedaan hasil pengujian hipotesis di dapatkan data bahwa dari 40 responden sectio cesaria, hasil uji hipotesis dengan menggunakan uji Z (Wilcoxon), pada kelompok kontrol dan intervensi $\begin{array}{lllll}\text { menghasilkan } & \text { p-value } & 0.000 & <\alpha & 0.005\end{array}$ bermakna Ho ditolak. Hal ini dapat disimpulkan bahwa pengeluaran ASI dengan diberikannya pijat oksitosin ada pengaruh yang signifikan terhadap ibu post partum sectio caesar (SC).

\section{Pembahasan}

Berdasarkan hasil penelitian terhadap 40 responden di Ruang Kalimaya Bawah RSUD dr. Slamet Garut antara kelompok kontrol dan intervensi. Hal ini dapat diketahui hasil dari analisa statistik non parametrik dengan melakukan uji hipotesis uji wilcoxon menyatakan uji statistik wilcoxon menunjukkan hasil $\mathrm{p}$ value $=$ $0,000<\alpha(0,005)$, bermakna $H_{0}$ ditolak dan $H_{1}$ diterima sehingga dapat disumpulkan ada perbedaan produksi ASI pada kelompok kontrol dan intervensi. Dari hasil penelitian produksi ASI setelah pemberian pijat oksitosin pada ibu post partum SC di Ruang Kalimaya Bawah RSU Dr. Slamet Garut menunjukan ada peningkatan nilai signifikan dibandingkan dengan kelompok kontrol yang tidak 
diberikan pijat oksitosin. Secara teori menurut Rahayu (2016), pijat ASI merupakan salah satu solusi untuk mengatasi ketidaklancaran produksi ASI.

Pijat ASI adalah pemijatan pada sepanjang tulang belakang (vertebrae) sampai tulang costae kelima-keenam dan merupakan usaha untuk merangsang hormon prolactin dan oksitosin setelah melahirkan. Oksitosin adalah salah satu dari dua hormon yang dibentuk oleh sel-sel neuronal nuclei hipotalamik dan juga disimpan dalam lobus posterior pituitary serta hormon lainnya yaitu vasopressin. Pada hormon nevasopressin ini memiliki fungsi untuk bekerja mengkontraksi uterus dan menginjeksi Air Susu Ibu (Suherni, Hesti dan Anita, 2009).

Intervensi berupa pijat oksitosin pada ibu post partum dapat memicu pengeluaran air susu dari payudara. Pemicu terpenting untuk mengeluarkan oksitosin adalah rangsangan fisik pada puting payudara. Bukti menunjukan bahwa oksitosin juga sangat berperan dalam mempererat hubungan ibu dan bayinya karena ada reseptor-reseptor otak untuk oksitosin yang diyakini memfasilitasi hormon yang terkait perilaku keibuan. Oksitosin dilepaskan sedikit kira-kira 7,5 sentimeter dia tas tualang besar yang menonjol di permukaan dalam tumit serta oksitosin juga akan membantu dalam involusi uterus serta mencegah pendarahan pada pasca persalinan (Rahayu, 2016).
Hasil penelitian ini juga dikuatkan dengan pendapat yang dikemukakan olehRahayu (2016), pijat oksitosin juga mempengaruhi kondisi psikologis ibu menyusui. Saat ibu merasa nyaman dengan dilakukan pijat oksitosin, pada saat menyusui dengan perasaan rileks maka pengeluaran oksitosin akan dapat berlangsung dengan baik, serta terdapat titik-titik yang dapat memperlancar ASI diantaranya, tiga titik di payudara yakni titik di atas puting, titik tepat pada puting dan titik dibawah puting, serta titik di punggung yang segaris dengan payudara.

Salah satu upaya untuk memperancar produksi ASI yaitu dengan cara memberikan pijat oksitosin pada ibu post partum tindakan tersebut dilakukan oleh tenaga kesehatan, keluarga, ataupun oleh suami akan memberikan kenyamanan pada ibu, sehingga akan memberi kenyamanan pada bayi yang disusui. Pijat oksitosin sangat tepat jika implementasi keperawatan atau kebidanan untuk ibu post partum yang belum ada pengeluaran ASI dilakukan pijat oksitosin (Rahayu, 2016). Hasil penelitian ini sejalan dengan penelitian Rahayu dan Andriyani (2014), yang berjudul "Metode Memperbanyak Produksi ASI Pada Ibu Post Sectio Caesarea Dengan Tehnik Marmet Dan Breast Care Di RSUD Karanganyar", menunjukan bahwa tidak ada perbedaan tekhnik marmet dan breast care terhadap produksi ASI. Fenomena di lapangan 
terhadap pengaruh pijat oksitosin, penelitian ini dilakukan pada ibu post partum SC pada saat 8 jam post partum atau setelah ibu post partum melakukan mobilisasi dini di runag nifas Kalimaya Bawah RSUD dr. Slamet Garut.

Pada halnya dengan dilakukan pijat oksitosin selain memperlancar ASI pijat oksitosin memberikan kenyamanan pada ibu post partum, mengurangi sumbatan ASI, merangsang pelepasan hormon oksitosin, yang dirasakan ibu post partum saat dilakukan pijat oksitosin merasa nyaman hal ini, ibu merasa rileks adalah syarat keberhasilan dalam pijat oksitosin. Dalam penelitian ini pijat oksitosin berpengaruh terhadap pengeluaran ASI ibu post partum SC.

Penelitian dengan dilakukannya tindakan pijat oksitosin, maka pengeluaran ASI ibu post partum akan lebih teratasi sehingga pemberian ASI ekslusif terhadap bayi terpenuhi. Hal ini sesuai yang dikemukakan oleh (Prasetyono, 2009),ASI merupakan jenis makanan yang dapat mencukupi seluruh unsur kebutuhan bayi baik fisik, fsikologi, sosial maupun spiritual. ASI juga mengandung nutrisi, hormon, unsur kekebalan tubuh, anti alergi serta anti imflamasi. Salah satunya yaitu kolostrum yang banyak mengandung sel darah putih, protein dan antibodi yang dapat memberikan perlindungan bayi sampai usia 6 bulan.

\section{KESIMPULAN DAN SARAN}

\section{Kesimpulan}

a. Rata-rata ibu post partum SC kelompok kontrol hampir setengahnya (30\%) pada hari ketiga tidak mengeluarkan ASI.

b. Rata-rata ibu post partum SC kelompok intervensi seluruhnya (100\%) pada hari ketiga tindakan 5 mengeluarkan ASI.

c. Ada pengaruh yang signifikan produksi ASI pada ibu post partum SC setelah dilakukan pijat oksitosin di RSUD dr. Slamet Garut.

\section{Saran}

a. Bagi Institusi

Hasil penelitian hendaknya dijadikan sebagai bahan pengetahuan dalam kepustakaan keperawatan maternitas khususnya mengenai efektifitas pijat oksitosin terhadap produksi Air Susu Ibu (ASI) pada ibu post partum.

b. Bagi Penelitian Selanjutnya

Diharapkan adanya penelitian lebih lanjut untuk mendapatkan informasi lebih mendalam mengenai efektifitas pijat oksitosin terhadap produksi Air Susu Ibu (ASI) pada ibu post partum dengan jenis penelitian, metode dan sampel berbeda dan lebih besar lagi agar didapat hasil yang lebih akurat.

c. Bagi Pihak RSUD dr. Slamet Garut Berdasar hasil penelitian diharapkan perawat mampu memberikan asuhan keperawatan/asuhan kebidanan yang 
komprehensif menangani pasien post partum dalam tindakan mandiri perawat (nursing therapheutic intervention), sehingga pengelolaan pelayanan kesehatan pasien tidak hanya berfokus pada asfek medis (pengobatan dan tindakan invasive). Selain itu, penelitian ini diharapkan menjadi salah satu rujukan bagi pihak rumah sakit dalam menyusun atau menetapkan SOP pengelolaan/ intervensi terhadap pasien post partum yang belum mengeluarkan ASI pada hari pertama berdasarkan kajian empirik yang telah dilakukan.

d. Bagi Pembaca

Diharapkan bisa memberi tindakan pijat oksitosin terhadap kelancaran ASI pada ibu post partum.

1, 2, 3 STIKes Karsa Husada Garut

\section{DAFTAR PUSTAKA}

Asiyah, Wigati. (2015). Minyak Aromaterapi Lavender Sebagai Media Peningkatan Produksi ASI. Diakses melalui <online> http://ejr.stikesmuh kudus.ac.id/index.php/jikk/article/vie $\mathrm{w} / 137 .[28 / 11 / 2017]$

Atikah. (2010). Imunisasi dan Vaksinasi. Catatan Pertama. Yogyakarta: Nuhamedika

Bobak. (2010). Buku Ajar Keperawatan Maternitas. Jakarta: EGC

Bahiyatun. (2009). Buku Ajar Asuhan Kebidanan Nifas Normal. Jakarta: EGC

Budiarto, Anggraeni. (2008). Pengantar Epidemiologi, Edisi 2. Jakarta: EGC

Budiasih,Sri. (2008). Handbook Ibu Menyusui. Bandung: Karyakita
Cuningham, FG., Etal. (2013). Obstetri William (William Obstetri). Jakarta: EGC

Dahlan, Sopiyudin. (2010). Besar Sampel dan Cara Pengambilan Sampel. Jakarta: Salemba Medika

DepkesRI. (2014). Misi Indonesia Sehat. Diambil 22 januari 2018 diakses melalui <online> http://www.Dep kes.go.id

Dinkes Kab. Garut. (2017). Profil Kesehatan Kabupaten Garut Tahun 2017 Fatimah

F.B Berliana Monika Purba. (2014). Buku Pintar ASI dan Menyusui. Jakarta: Noura Book

Geri, Morgan dan Carol Hamilton. (2009). Obstetri dan Ginekologi Panduan Praktik. Jakarta: EGG

Gunanegara, dkk. (2010). Efektivitas Ekstrak Daun Katuk dalam Produksi Air Susu Ibu untuk Keberhasilan Menyusui. Diakses melalui <online> http://scholer.google.co.id/scholer_ur 1/url $=$ http $\% 3 \mathrm{~A} \% 2 \mathrm{~F} \% 2 \mathrm{~F}$ jurnal ke dokteran $\% 2 \mathrm{~F}$ article $\% 2 \mathrm{~F}$ download\# $\mathrm{F} 820 \% 2 \mathrm{Fdf} \& \mathrm{sa}=\mathrm{T} \&$ oi $=$ ggp $\quad \& \mathrm{ct}=\mathrm{res}$ $\& \mathrm{~cd}=0 \& \mathrm{ei}=\mathrm{uHSZWvaBIT}$ tjwStn6T gDA\&scicig $=\mathrm{AABfm} 3 \mathrm{c} 3$ D5XIAw4 0qQ8cdT5TpFWNwNi2w \&nossl=1 $\& w s=360 \times 517$. [28/11/2017]

Hubertin, Sri Purwanti. (2014). Konsep Penerapan ASI Ekslusif. Jakarta: ECG

Manuaba. (2015). Pengantar Kuliah Obstetri. Jakarta: EGC

Mardani. (2015). Asfek Hukum Lembaga Keuangan Syariah di Indonesia. Edisi I. Jakarta: KENCANA

Manuaba. (2008). Ilmu Kebidanan Penyakit Kandungan dan KB. Jakarta: ECG

Notoatmodjo, Soekidji. (2010). Metodologi Penelitian Kesehatan. Jakarta : RinekaCipta

Nurheti, Yuliarti. (2010). Keajaiban ASI_Makanan terbaik untuk Kesēhatan Kecerdasan dan Kelincahan Si Kecil. Jogyakarta: CV. ANDI Offset

Prasetyono D.S. (2009). ASI Ekslusif Pengenalan, Praktik dan 
Pemanfaatan Kemanfaatannya: Diva Press.Yogyakarta

Perinasia. (2011). Bahan Bacaan Manajemen Laktasi. Jakarta: EGC

RisaPitriani, Rika Andriyani. (2015). Panduan Lengkap Asuhan Kebidanan Ibu Nifas Normal (Askeb III): Deepublish

Rahayu, Andriyani. (2014). Metode Memperbanyak Produksi Asi Pada Ibu Post Sectio Caesarea Dengan Tehnik Marmet Dan Breast Care Di RSUD Karanganyar. Diakses melalui <online> http://www.jurnal. stikes-aisyiyah.ac.id/index.php/gas ter/article/ view/78 [28/12/2017]

Rahayu, Anik Puji. (2016). Panduan Praktikum Keperawatan Maternitas. Edisi 1. Yogyakarta: Deepublish
RSU dr.Slamet Garut. (2017). Data Ibu Post Partum 2017: KabupatenGarut

Soetjiningsih. (2012). Perkembangan Anak dan Permasalahan dalam Buku Ajar 1 Ilmu Perkembangan Anak dan Remaja. Jakarta: EGC

Soetjiningsih. (2012). ASI Petunjuk Untuk Tenaga Kesehatan. Jakarta: EGC

Siregar, Charles J.P. (2008). Teknologi Farmasi Sediaan Tablet. DasarDasarPraktis. Jakarta: EGC

Simkin, Penny, dkk. (2008). Panduan Lengkap Kehamilan Melahirkan dan Bayi. Jakarta: EGC

Sutanto. 2009. Awas 7 Penyakit Degeneratif. Pradigma Indonesia: Yogyakarta

Suherni, Widyasih, dkk. 2009. Perawatan Masa Nifas. Jakarta: Fitramaya 